\title{
Candida albicans'ın Eşey Tipi Gen Bölgesinin Belirlenmesi
}

\author{
Investigation of the Mating-Type Gene Locus of Candida albicans

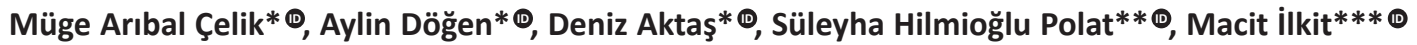 \\ *Mersin Üniversitesi Eczacılık Fakültesi, Farmasötik Mikrobiyoloji Anabilim Dalı, Mersin, Türkiye \\ **Ege Üniversitesi Tıp Fakültesi, Tıbbi Mikrobiyoloji Anabilim Dalı, İzmir, Türkiye \\ ***Çukurova Üniversitesi Tıp Fakültesi, Tıbbi Mikrobiyoloji Anabilim Dalı, Adana, Türkiye
}

Alındığı tarih / Received:

08.10.2019 / 08.October.2019

Kabul tarihi / Accepted:

21.12.2019 / 21.December.2019

Yayın tarihi / Publication date:

31.06.2020 / 31.June.2020

\section{ORCID Kayıtları}

M. Arıbal Çiçek 0000-0002-2255-1183

A. Döğen 0000-0002-0388-306X

D. Aktaş 0000-0001-8580-4152

S. H. Polat 0000-0001-8850-2715

M. Illkit 0000-0002-1174-4182

aylinats@mersin.edu.tr

Atıf: Arıbal Çelik M. Döğen A, Aktaş D, Hilmioğlu Polat S, ilkit M. Candida albicans'ın eşey tipi gen bölgesinin belirlenmesi. Turk Mikrobiyol Cemiy Derg. 2020;50(2):95-9. öz

Amaç: Askomiset mantarlarda çiftleşme, MAT lokus adı verilen bir eşey tipi gen bölgesi ile yönetilir. MAT lokus, zıt iki eşey tipinde birbirine benzemeyen hatta tamamen farklı idiomorf dizilimler içerir. Pezizomycotina alt şubesine dâhil olan mantarlarda her bir MAT idiomorfu, bir alfa domain, bir de HMG (High Mobility Group) domain transkripsiyon faktörünü kodlar. Alfa domain ve HMG domain transkripsiyon faktör genleri MAT lokusun olmazsa olmaz parçaları olsa da her bir mantarın MAT lokus yapısı, yani uzunluğu, gen içeriği ve genlerin transkripsiyon yönleri kendilerine özgüdür. Bu çalışmada, laboratuvarlarımızın kültür koleksiyonunda bulunan ve kan kültürlerinden izole edilen Candida albicans'ın eşey tipi gen bölgesinin karakterizasyonunun belirlenmesi amaçlanmıştır.

Yöntem: Candida albicans genomunda yer alan MTLa (Mating Type Locus)ve MTL $\alpha$ primerlerinin 485 bp ve 515 bp'lik DNA bölgesi multiplex PCR tekniği ile belirlendi.

Bulgular: Toplam, 156 C. albicans kökeninin 155 (\%99.4)'i MTLa/a, 1 (\%0.6) köken ise $M T L \alpha / \alpha$ olarak bulundu.

Sonuç: MTL karakterizasyonun belirlenmesi çalışmaları hem moleküler genetik çalışmalarının daha kolay ve çabuk yapılabilmesi hem de bu patojen mantarın doğasının anlaşılması yönünden önemlidir.

Anahtar kelimeler: Candida albicans, eşeyli üreme, MTL lokus, virulans

\section{ABSTRACT}

Objective: Mating in Ascomycete fungi is governed by mating type gene region called the MAT locus. The MAT locus contains idiomorphic sequences that are dissimilar in two opposite mating types.In fungi belonging to the Pezizomycotina subphylum, each MAT idiomorph encodes an alpha domain and an HMG (High Mobility Group) domain transcription factor. Although the alpha domain and the HMG domain transcription factor genes are indispensable components, the structure of the MAT locus (length), the gene content, and the transcriptional directions of the genes differ among fungi. This study aimed to evaluate the characterization of mating type of Candida albicans isolated from blood samples in our labouratory culture collection.

Method: Using the multiplex PCR technique, $486 \mathrm{bp}$ and $515 \mathrm{bp}$ of the DNA region of MTLa and MTL $\alpha$ primers in the C. albicans genome were determined, respectively. Results: 156 C. albicans isolates showed 155 MTLa/ $\alpha$ (99.4\%) and 1 MTL $\alpha / \alpha$ (0.6\%). Conclusion: Determination of MTL is essential both for making molecular genetic studies more efficient and for understanding the nature of this pathogenic fungus.

Keywords: Candida albicans, sexual reproduction, MAT locus, virulence

(c) Telif hakkı Türk Mikrobiyoloji Cemiyeti'ne aittir. Logos Tıp Yayıncılık tarafindan yayınlanmaktadır. Bu dergide yayınlanan bütün makaleler Creative Commons Atf-Gayri Ticari 4.0 Uluslararası Lisansı ile lisanslanmıştır. 


\section{Giriş}

Candida albicans, eşeyli çoğalan, diploid bir maya mantarı olup, insanlarda ağız ve vagina enfeksiyonlarının etkenidir. Askomiset mantarlarda eşleşme, MAT lokus adı verilen bir eşey tipi gen bölgesi tarafından yönetilir. MAT lokus, idiomorf dizilimleri içerir ve her bir MAT idiomorfu alfa domain ve HMG domain transkripsiyon faktörünü kodlar. Her mantarın MAT lokus yapısı yani uzunluğu, gen içeriğ ve genlerin transkripsiyon yönleri kendilerine özgüdür. Ayrıca, MAT lokus gen bölgesi, hücre tipi kimlik oluşturan, eşeyli üremeye yardımcı olan ve bazı durumlarda virulans ile bağlantılı transkripsiyon faktörlerini (homeodomain, HMG ve a-domain) veya feromon reseptörlerini $\operatorname{kodlar}^{(1)}$.

Candida albicans'ın mating type benzeri (MTL) lokusu Saccharomyces cerevisiae'nin a1, $\alpha 1$ ve $\alpha 2$ 'ye ek olarak a2 regülatörleri ile hücresel kimliğin transkripsiyon regülatörleri arasında benzerlik gösterir. Candida albicans'ın MTL lokusu, fosfatidilinositolkinazları (PIK), oksistein bağlayıcı proteinleri (OBP) ve poliA polimerazları (PAP) kodlayan genleri ihtiva etmesi nedeniyle Saccharomyces cerevisiae'den daha büyük olduğu belirtilir(2)

Bu çalışmada, Candida albicans'ın eşey tipinin belirlenmesi amaçlanmıştır.

\section{GEREÇ ve YÖNTEM}

Mersin Üniversitesi Eczacılık Fakültesi Farmasötik Mikrobiyoloji Anabilim Dalı, Çukurova Üniversitesi Tıp Fakültesi Mikrobiyoloji Anabilim Dalı ve Ege Üniversitesi Tıp Fakültesi Mikrobiyoloji Anabilim Dalı kültür koleksiyonlarında bulunan ve kan kültürlerinden elde edilen toplam 156 C. albicans kökeni çalışmaya alındı. C. albicans tanısı konvansiyonel ve moleküler yöntemlerle doğrulandı. Kontrol kökeni olarak C. albicans ATCC 10231, ATCC 24433 ve ATCC 90028 kullanıldı.

Konvansiyonel yöntemler: Stok kültür koleksiyonla- rında C. albicans kayıtlı suşlar Sabouraud glukoz agar'a (SGA; Sigma-Aldrich, St. Louis, MO, ABD) ve BBL CHROMagar Candida (BectonDickinson, Sparks, $M D, A B D$ ) besiyerine aynı anda pasajlandı ve $37^{\circ} \mathrm{C}^{\prime} \mathrm{de}$ 72 saat inkübe edildi. Üretici firmanın önerileri doğrultusunda BBL CHROMagar Candida besiyerinde yeşil renk koloni oluşturan kökenler germ tüp testi ile doğrulandı. Ayrıca, kökenler Mısırunu-Tween 80 agarda (HiMedia, Mumbai, Hindistan) yalancı hif, gerçek hif, blastospor ve klamidospor varlığı veya yokluğu yönünden incelendi(3).

Moleküler yöntemler: Konvansiyonel yöntemlerle doğrulanan kökenlerin moleküler testlerle de doğrulanması için kökenler yine SDA besiyerine pasajlandı ve taze kültür kolonilerinden DNA ekstraksiyonu Turin ve ark.'nın(4) önerdiği yönteme göre yapıldı. ITS 1-4 primerleri kullanılarak PCR amplifikasyonu, toplam hacim $25 \mu \mathrm{L}$ olacak şekilde [12.5 $\mu \mathrm{L} 2 \times$ karışım (AmpliqonTaq DNA Polymerase Master Mix, Odense, Danimarka); $0.5 \mu \mathrm{L}$ her bir primerden (100 pmol/ $\mu \mathrm{L}$ ), $10.5 \mu \mathrm{L}$ distile su ve $1 \mu \mathrm{L}$ kalıp DNA] gerçekleştirildi (Tablo 1). Isı döngü cihazı (Techne Prime, Staffordshire, İngiltere)'nda, PCR amplifikasyonu $95^{\circ} \mathrm{C}^{\prime}$ de 5 dakika ilk denatürasyonu takiben, 35 döngü $95^{\circ} \mathrm{C}^{\prime}$ de 45 sn denatürasyon, $57^{\circ} \mathrm{C}$ 'de 60 sn primer birleşmesi, $72^{\circ} \mathrm{C}^{\prime}$ de 60 sn çoğaltma ve $72^{\circ} \mathrm{C}^{\prime}$ de 5 dakika son uzama olarak optimize edildi. PCR amplifikasyonu sonrasında elektroforez ile \%1.2'lik agaroz jelde 120 voltta $30 \mathrm{dk}$ yürütülen örnekler jel görüntüleme cihazında incelendi. Hedeflenen 535 bp bölgede bant gözlenen PCR örnekleri saflaştırıldıktan sonra, primer çiftinin ileri primerleri kullanılarak RefGen Biyoteknoloji ve Araştırma Merkezi (ODTÜ, Ankara)'nde sekans reaksiyonları yapıldı.

Eşey gen bölgesinin araştırılması: Eşey tipinin saptanması amacıyla C. albicans genomunda yer alan MTLa ve MTLa primerleri (Tablo 1 ) ile yapılan amplifikasyonda, $94^{\circ} \mathrm{C}$ 'de 3 dakika ilk denatürasyon sonrası, 35 döngü $94^{\circ} \mathrm{C}^{\prime}$ de 1 dakika denatürasyon, $55^{\circ} \mathrm{C}^{\prime}$ de 1 dakika primer birleşmesi, $72^{\circ} \mathrm{C}^{\prime}$ de 1 dakika çoğaltma ve takiben $72^{\circ} \mathrm{C}$ 'de 7 dakika son uzama 
gerçekleştirildi. PCR ürünleri elektroforez ile \%3 agarozjelde 100 voltta 120 dakika yürütüldü. Jel translüminatörde ultraviyole ışık altında incelendi. Çalışmada, MTLa için 485 bp ve MTL $\alpha$ için ise 515 bp uzunluğundaki bölgede bant gösteren örnekler değerlendirildi.

Tablo 1. Amplifikasyonda kullanılan primerler ${ }^{(17)}$.

\begin{tabular}{|c|c|c|}
\hline $\begin{array}{l}\text { Primer } \\
\text { Adı }\end{array}$ & Primer & Nükleotid dizileri (5'-3') \\
\hline ITS1 & Forward primer & 5'-TCCGTAGGTGAACCTGCGG-3' \\
\hline ITS4 & Reverse primer & 5'-TCCTCCGCTTATTGATATGC-3' \\
\hline MTLa & Forward primer & 5'-TTC GAG TAC ATT CTG GTC GCG-3' \\
\hline MTLa & Reverse primer & 5'-ATC AAT TCC CTT TCT CTT CGA TTA GG-3' \\
\hline$M T L \alpha$ & Forward primer & ' 5'-TTG AAG CGT GAG AGG CTA GGA-3' \\
\hline$M T L \alpha$ & Reverse primer & 5'-TGT AAA CAT СCT CAA TTG TAC CCG A-3' \\
\hline
\end{tabular}

Bu çalışma, Mersin Üniversitesi Bilimsel Araştırma Projeleri Birimi tarafından 2017-2-TP2-2585 nolu proje olarak desteklenmiştir.

\section{BULGULAR}

Mersin Üniversitesi Farmasötik Mikrobiyoloji Anabilim Dalı kültür koleksiyonunda bulunan 156 C. albicans izolatı çalışmaya alındı. Stok kültüründen Sabouraud dekstroz agar ve BBL CHROMagar Candida'ya canlandırma yapıldı. Canlandırma sonrası üreyen her bir yeşil renkli kökeni, çimlenme borusu oluşturma ve mısır unu-tween 80 agardaki mikromorfolojik özelliklerine göre değerlendirildi.
Tür tanımı yapılması için yeterli olan özellikler kadedilip moleküler yöntemlerle $C$. albicans olduğu doğrulandı.

Candida albicans genomunda yer alan MTLa ve MTL $\alpha$ primerlerinin kullanılarak belirlendiği eşey tip gen bölgesin 485 bp ve 515 bp'lik DNA bölgesi multiplex PCR tekniği ile kullanılarak belirlendi.

Çalışmada, tür tanısı doğrulanan 156 C. albicans kökeninin 1'i MTLa (\% 0.6) ve $155^{\prime}$ inin ise (\% 99.4) MTLa/MTLa olduğu belirlendi. Sonuçlara ait PCR jel görüntüsü Şekil 1'de görülmektedir.

\section{TARTIŞMA}

Insanlarda hastalık etkeni mantarlar arasında en sık belirlenen türlerden birisi de C. albicans'dır. C. albicans'ın 1999'a dek aseksüel olduğu düşünülmekte idi(2). Bu düşünce, $M T L$ lokusun olmayışı veya eşey tipi füzyonun gözlenmeyişi gibi eksik bilgilerden kaynaklanıyordu. MTL identifikasyonunu gösteren tüm genom projelerinde C. albicans'ın MTL lokusu gösterilmiştir. Son zamanlarda virulans ile ilişkili faktörleri kodlayan MAT lokus gen bölgesi özellikle dikkat çekmektedir ${ }^{(5-9)}$. Askomiset mantarlarda eşleşme yüksek derecede farklılaşmış sekanslara sahip iki idiomorflu tek bir eşleşme tipi (mating tip-MAT) lokusu tarafından yönetilmektedir. C. albicans diploid bir

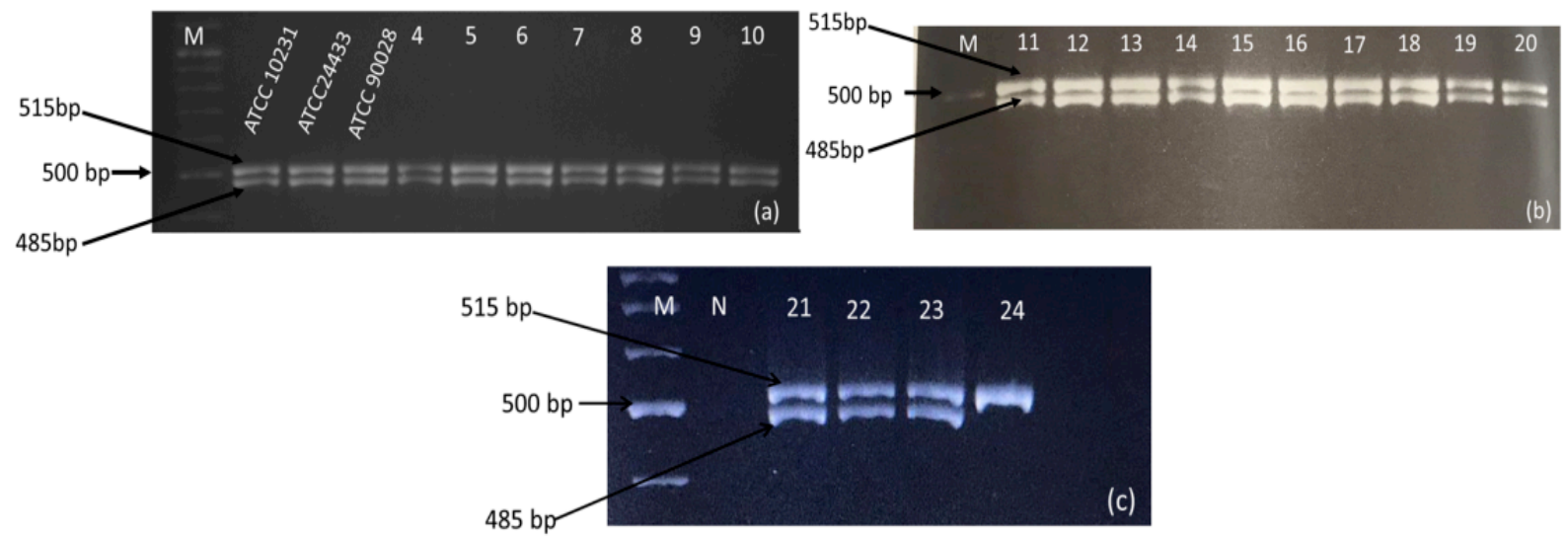

Şekil 1. Eşey gen bölgesine ait PCR jel görüntüsü; (a) M: Marker, Candida albicans ATCC 10231, C. albicans ATCC24433 ve C. albicans ATCC 90028, 4-10, (b) M: Marker, 11-20, (c): M: Marker, N: Negatif kontrol, 21-23 MTLa/MTL $\alpha$ eşey gen bölgesine sahip C. albicans kökenleri, 24: $M T L \alpha$ eşey gen bölgesine sahip $C$. albicans kökeni. 
mikroorganizmadır. MTL gen bölgesi çoğunlukla heterozigot olup, a/ $\alpha$ allellerini taşımaktadır. Ancak, klinik izolatların \%57'sinde a/a veya $\alpha /$ /homozigotluğu mevcuttur ve potansiyel çaprazlaşma yeteneğine sahiptir(2). Ayrıca, MTL lokusunu taşıyan kromozon üzerinde azol etkinliğini belirleyen ERG11 ve TAC1 genleri bulunduğu için azollere karşı dirençli olan C. albicans suşlarında MTL bölgesinde homozigotluk oranı fazladır ${ }^{(10,11)}$.

MTL sisteminin keşfinden sonra, beyazdan opaklığa geçişin eşleşme sürecinde önemli bir adım olduğu ortaya konulmuştur. Anaerop kültür, yüksek $\mathrm{CO}_{2}$ düzeyleri, $\mathrm{N}$-asetil glikozamin (aynı zamanda saprofit bakterilerin bir ürünü), oksidatif stres ve hücrenin yavaş büyümesi opaklığa geçişte rol oynayan önemli etkenler arasında yer alır ${ }^{(12,13)}$.

Ibrahim ve ark. ${ }^{(14)} \mathrm{C}$. albicans'ın beyaz-opak fenotipik dönüşümü gösteren suşlarında, opak hücrelerde eşleşmenin daha fazla olduğu, "opak" hücreler tarafından üretilen $\alpha$ feromonun "beyaz" hücrelerde biyofilm üretimini artırdığını bildirmişlerdir.

Candida albicans hücrelerinin en çok deride $\left(31-32^{\circ} \mathrm{C}\right)$ eşleşme yaptığı belirtilmiştir(15). Çin'de yapılan çalışmada, çeşitli kliniklerden izole edilen 93 C. albicans kökeninin 86 (\%92.5) MTLa/a eşey tipi olduğunu, yalnızca yedi kökenin ise (\%6.5) MTLa/a veya $\alpha / \alpha$ eşey tipi olduğu rapor edilmiştir. Aynı çalışmada, 27 kökenin beyaz koloni, 66 kökenin opak koloni oluşturduğu ve eşey tipinin ise heterozigot olduğu bildirilmiştir(16).

Lockhart ve ark. ${ }^{(17)}$ MTLa/ $\alpha$, MTLa/a, MTLa/ $\alpha$ eşey tipine ait $C$. albicans kökenlerini farelere enjekte etmişler ve $M T L a / \alpha$ suşunun, MTLa/a veya $M T L \alpha / \alpha$ kökenlerine göre fareyi çok daha hızlı öldürdüğünü, bu nedenle MTLa/ $\alpha$ eşey tipine sahip kökenlerin daha virülan olduğunu, yine Lockhart ve ark. ${ }^{(18)} 220$ C. albicans klinik kökeninin \%96.8'sının MTLa/ $\alpha$ ve \%3.2'sinin homozigot olduğunu (MTLa/a veya $M T L \alpha / \alpha)$ bildirmişlerdir.
Park ve ark. ${ }^{(19)}$ insanlardan izole edilen $C$. albicans suşlarının \%95'inden fazlası MTLa/ $\alpha$ olduğunu ve bunların yaklaşık $1 / 3^{\prime}$ inin beyaz formdan opak forma dönüşebileceğini, iki transkripsiyon faktörünün (TFs), $S f l 2$ ve $E f g 1$ 'in a/ $\alpha$ suşlarında fenotipik değişimin baskıladığını bildirmişlerdir. Bir başka çalışmada ise, C. albicans'ın orofaringeal kandidoz izolatlarına ilişkin opak hücrelerin oral mukoza epitel hücrelerini daha az invaze ettiği ve Candida'nın eşleşmesinin ender olduğunu gösterilmiştir ${ }^{(20)}$.

Sunulan çalışmada ise kan kültürlerinden elde edilen 156 C. albicans suşunda 155 (\%99.4)'i MTLa/a ve 1 $(\% 0.6)^{\prime} \mathrm{i} \quad M T L \alpha / \alpha$ olarak literatürlerle uyumlu bulundu.

Sonuç olarak, mantarlarda bir eşeyli çoğalmada rol oynayan genlerin virülans ve patogenezdeki rolleri anlaşıldıkça, mikozların tanısında ve farklı hedeflere yönelik yeni tedavi yaklaşımlarının geliştirilmesi ve/ veya mevcut tedavi yöntemlerinin yönlendirilmesine yol gösterici olacaktır.

\section{KAYNAKLAR}

1. Heitman J. Evolution of eukaryotic microbial pathogens via covert sexual reproduction. Cell Host Microbe. 2010;8(1):86-99. https://doi.org/10.1016/j.chom.2010.06.011

2. Hull CM, Johnson AD. Identification of a mating typelike locus in asexual pathogenic yeast Candida albicans. Science. 1999;285(5431):1271-5. https://doi.org/10.1126/science.285.5431.1271

3. Deorukhkar SC, Roushani S. Identification of Candida species: conventional methods in the era of molecular diagnosis. Ann Microbiol Immunol. 2018;1(1):1002.

4. Turin L, Riva F, Galbiati G, Cainelli T. Fast, simple and highly sensitive double-rounded polymerase chain reaction assay to detect medically relevant fungi in dermatological specimens. Eur J Clin Invest. 2000;30(6): 511-8. https://doi.org/10.1046/j.1365-2362.2000.00659.x

5. Çerikçioğlu N. Mantarlarda çaprazlaşma tipleri, eşeyli çoğalma ve ploidinin virülans üzerine etkileri. Mikrobiyol Bul. 2009;43(3):507-13.

6. Coppin E, Debuchy R, Arnaise S, Picard M. Mating types and sexual development in filamentous ascomycetes. Microbiol Mol Biol Rev. 1997;61(4):411-28. 
7. Guobo G, Tao L, Yue H, et al. Environment-induced same-sex mating in the yeast Candida albicans through the Hsf1-Hsp90 pathway. PLoS Biol. 2019;17(3): e2006966.

https://doi.org/10.1371/journal.pbio.2006966

8. Boral H, Metin B, Döğen A, Seyedmousavi S, Ilkit M. Overview of selected virulence attributes in Aspergillus fumigatus, Candida albicans, Cryptococcus neoformans, Trichophyton rubrum, and Exophiala dermatitidis. Fungal Genet Biol. 2018;111:92-107. https://doi.org/10.1016/j.fgb.2017.10.008

9. Lee SC, Ni M, Li W, Shertz C, Heitman J. The evolution of sex: a perspective from the fungal kingdom. Microbiol Mol Biol Rev. 2010;74(2):298-340. https://doi.org/10.1128/MMBR.00005-10

10. Heitman J. Sexual reproduction and the evolution of microbial pathogens. Curr Biol. 2006;16(17):R711-25. https://doi.org/10.1016/j.cub.2006.07.064

11. Ou TY, Chang FM, Cheng WN, et al. Fluconazole induces rapid high-frequency MTL homozygosis with microbiological polymorphism in Candida albicans. J Microbiol Immunol Infect. 2017;50(6):899-904. https://doi.org/10.1016/j.jmii.2015.12.009

12. Ramírez-Zavala B, Reuss O, Park YN, Ohlsen K, Morschhäuser J. Environmental induction of whiteopaque switching in Candida albicans. PLoS Pathog. 2008;4(6):e1000089. https://doi.org/10.1371/journal.ppat.1000089

13. Daniels KJ, Srikantha T, Lockhart SR, Pujol C, Soll DR. Opaque cells signal white cells to form biofilms in Candida albicans. EMBO J. 2006;25(10):2240-52. https://doi.org/10.1038/sj.emboj.7601099
14. Ibrahim AS, Magee BB, Sheppard DC, et al. Effects of ploidy and mating type on virulence of Candida albicans. Infect Immun. 2005;73(11):7366-74. https://doi.org/10.1128/IAI.73.11.7366-7374.2005

15. Nielsen K, Heitman J. Sex and virulence of human pathogenic fungi. Adv Genet. 2007;57:143-73. https://doi.org/10.1016/S0065-2660(06)57004-X

16. Li HM, Shimizu-Imanishi Y, Tanaka R, Li RY, Yaguchi T. White-opaque switching in different Mating Type-like Locus gene types of clinical Candida albicans isolates. Chin Med J (Engl). 2016;129(22):2725-32. https://doi.org/10.4103/0366-6999.193442

17. Lockhart SR, Wu W, Radke JB, Zhao R, Soll DR. Increased virulence and competitive advantage of a/alpha over a/a or alpha/alpha off spring conserves the mating system of Candida albicans. Genetics. 2005;169(4): 1883-90. https://doi.org/10.1534/genetics.104.038737

18. Lockhart SR, Pujol C, Daniels KJ, et al. In Candida albicans, white-opaque switchers are homozygous formating type. Genetics. 2002;162(2):737-45.

19. Park YN, Conway K, Conway TP, Daniels KJ, Soll DR. Roles of the transcription factors Sfl2 and Efg1 in white-opaque switching in $a / \alpha$ strains of Candida albicans. mSphere 2019;4(2): e00703-18. https://doi.org/10.1128/mSphere.00703-18

20. Solis NV, Park YN, Swidergall M, Daniels KJ, Filler SG, Soll DR. Candida albicans white-opaque switching influences virulence but not mating during oropharyngeal candidiasis. Infect Immun. 2018;86(6):e00774-17. https://doi.org/10.1128/IAI.00774-17 